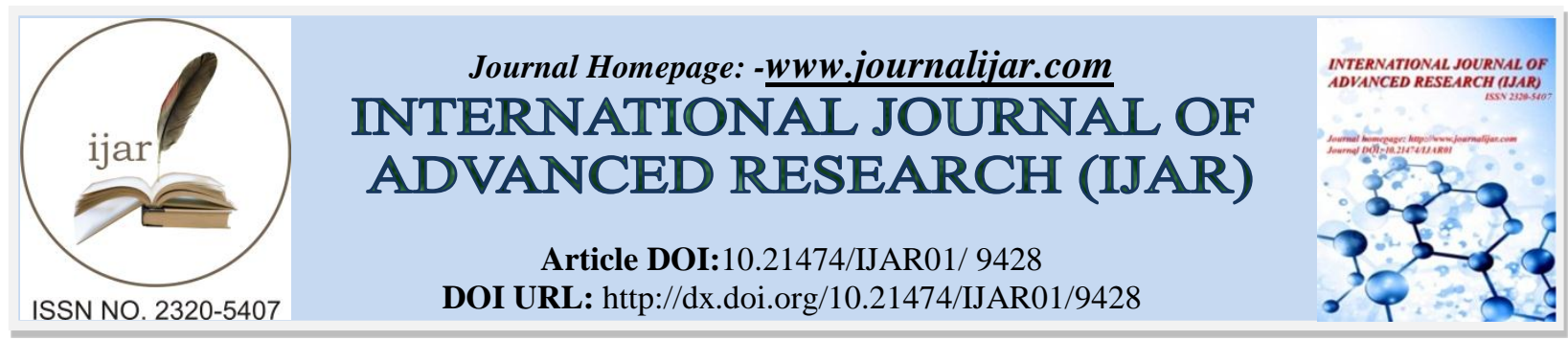

RESEARCH ARTICLE

\title{
DEVELOPMENT OF A BIOGAS PLANT FROM COW DUNG, SWINE DUNG AND POULTRY DROPPING.
}

S.A. Fasoyin and W.A. Akinfiresoye.

Department of Agricultural and Bio-Environmental Engineering Technology, Rufus Giwa Polytechnic. Akure. Nigeria.

\section{Manuscript Info}

Manuscript History

Received: 24 May 2019

Final Accepted: 26 June 2019

Published: July 2019

Key words:-

Biogas, renewable energy, cow dungs, swine dungs, poultry droppings.

\section{Abstract}

Over dependent on crude oil in African countries call for the need for alternative source of renewable energy. A biogas digester of 56 liters capacity was locally designed, fabricated and tested at the workshop of Agricultural and Bio-Environmental Engineering Department of Rufus Giwa Polytechnic, Owo, Nigeria. The major components of the biogas include the digestion chamber comprising of stirrer which can be manually or electrically powered, a thermometer to measure the temperature variations of the digester and the hygrometer to measure the relative humidity of the environment. Investigations were made into the production of biogas from the mixture of three different substrates of cow dung, swine dung and poultry droppings. The proximate analysis showed that volatile solid, total solid and moisture content for the mixed substrates at the initial stage were; $64.7 \%, 83.5 \%$ and $13.5 \%$ similarly at the digestion stage the volatile solid, total solid and moisture content were $54.1 \% 22.6 \%$ and $74.4 \%$. As the decomposition proceeded, the $\mathrm{pH}$ value gradually increased up to 7.2 and 7.4 indicating the stability of organic matter. Moisture content on wet basis was $13.5 \%$. These values latter increased to $74.4 \%$. On the average, 15 $\mathrm{kg}$ of mixed substrates with 25 liters of impure water produced biogas within 25 days of digestion. The gas produced from mixed substrates became flammable with blue flame after 16 days of production, indicating that the ratio of methane gas generated with three mixtures of fresh animal waste was higher than other gases produced. In conclusion, the mixed substrates produced faster than other substrates in mixture when compared to literatures. The cost of production was $38,805.75$, this price is considered been to be afforded by small and medium scale entrepreneurs.

Copy Right, IJAR, 2019,. All rights reserved.

\section{Introduction:-}

The rising cost of petroleum products is a serious problem facing most developing countries of the world including Nigeria which dwell on electricity for $98 \%$ of their source of Nigeria (Famuyide et al., 2004, CBN 2000). Again, excessive energy demands from both rural and urban dwellers imply that other natural sources of energy have to be explored. Hence, conversion of agricultural wastes into biogas could be a leeway to solving some of these energy

Corresponding Author:-S.A. Fasoyin.

Address:-Department of Agricultural and Bio-Environmental Engineering Technology, Rufus Giwa

Polytechnic. Akure. Nigeria. 
problems (Ofoefule and Uzodinma, 2009). However, due to epileptic electricity supply in Nigeria which has greatly reduce our daily income and lead to abnormal hike in foreign currency on daily market stock (Fagbenle et al., 2006), it is therefore important that Nigerian should embrace an alternative way by which electricity and cooking gas can be generated. According to Akinfiresoye et al. (2018) our environments are subjected to pollution and contamination leading to outbreak of killer diseases due to improper disposal of our domestic waste products. Rather than allowing this pollution to continue unabated, they can be converted through recycling into biogas production useful for our communities and nation. Nwaokocha and Giwa (2016) discovered in a related research that poor developing countries' households use wood, charcoal and other solid fuels to cook in open fires or poorly functioning stoves. It's a great challenge finding a means of expanding its energy resources especially to the rural households and also addressing the health risks and environmental consequences associated with over dependence on such fuels for cooking. While high consumption of firewood can lead to destruction of forest, the excessive smoke emitted can cause respiratory disorder when inhaled (Kehinde et al., 2014). Therefore, the need to utilize more animal dungs or agricultural wastes as an alternative energy source is apparent. Recently, diversification on the use of energy has increasingly become an important issue because the oil sources are costly and leads to pollution. Up till now, Nigeria focus more on petroleum, the existing PHCN power generation plants operate at far below their installed capacity as many of them have units that need to be rehabilitated, retrofitted, and upgraded (Imo, 2008). The percentage of generation capability from hydro turbines is $34.89 \%$; from gas turbine, $35.27 \%$; and from steam turbines, $29.84 \%$. The relative contribution of the hydropower stations to the total electricity generation (megawatt per hour) is greater than that of the thermal power stations (Oyedepo, 2012), therefore, an alternative source of energy is needed to solve the power challenge of Nigeria. In the study carried out by Zaher et al. (2009), Cow manure when urea or glucose is added produced methane with Carbon/Nitrogen $(\mathrm{C} / \mathrm{N})$ ratio between 15.5 and 19. Similarly, for swine manure, the greatest methane production is achieved when its $\mathrm{C} / \mathrm{N}$ is adjusted to $25 / 1$. The researcher found out that adding urea and glucose cannot be an economically sustainable method to facilitate methane generation from large scale digesters. Therefore, the productivity of anaerobic digestion process can be enhanced by optimizing the substrate $\mathrm{C} / \mathrm{N}$ ratio through the addition of other agricultural waste products such as maize husks, cassava peels, livestock dungs. The benefit of co-digesting plant material with animal manure can provide buffering capacity and a wide range of nutrients while the added plant materials with high carbon content can improve the $\mathrm{C} / \mathrm{N}$ ratio of the feedstock, thus potentially improving methane yields (Kayhanian, 2004).

\section{Materials and Methods:-}

Materials used for the fabrication of the biogas plants were selected based on their availability locally, suitability for the research and the cost. Cow dung (CD), Poultry dung (PD) and Swine dung (SD) were collected from Akure butchers plant along Ado Ekiti Road while PD was collected from Federal University of Technology poultry farm in Akure, Nigeria.

\section{Machine Conception}

The biogas plant was made up of cylindrical shaped chamber divided into the storage and digester units. It has a shaft carrying the stirrer suspended on two roller bearings at the ends of the chamber. There are controlled inlet and outlet valves at the upper part of the chamber and pressure gauge to determine the amount of gas produced. It also has an outlet at the base where the mixture of effluents and substrate is being released from the tank for further use in crop fertilization.

\section{Design Consideration}

Biogas reactor unit is a convectional machine that would interact with different waste such as plant and animal waste and also micro-organism in the process of production, with some high degree of strength, pressure and precision with consideration for cost and maintainability. Mild iron steel was used for the digestion chamber due to its strength, durability and resistance to corrosion. Low carbon mild steel was used for the shaft due to its ability to resist fatigue when mixing the waste inside the chamber and its toughness and strength to withstand loads.

\section{Design Analysis}

The major parts of the plant were designed as follows:

\section{Biogas plant digester capacity}

The volume, $\mathrm{V}$ of the cylindrical shape of the digester unit was designed according to the relationship in equation 2.1 by Allen et al., (2009)

$V=\pi r^{2} h$ 
Where $\pi$ is $22 / 7$ (constant), $r$ is the radius of the tank which is $255 \mathrm{~mm}, \mathrm{~h}$ is the height of the tank which is $275 \mathrm{~mm}$. Therefore,

$V=3.142 \times 255^{2} \times 275=5618.25 \mathrm{~mm}^{3}=56.2$ ltrs

\section{Shaft design}

The diameter of the shaft was determined using equation 2.2 according to Khurmi \& Gumpta (2005).

$$
d^{3}=\frac{16}{\pi s_{s}} \sqrt{\left(M_{t} k_{t}\right)^{2}+\left(M_{b} k_{b}\right)^{2}}
$$

Where $d$ is the diameter of the shaft $(\mathrm{mm}),\left(M_{b}\right)$ is the maximum bending moment $(\mathrm{Nm}),\left(M_{t}\right)$ is the torsional moment $(\mathrm{Nm}), K_{b}$ is the combined shock $=1.5, K t$ is the fatigue factor $=1.0$ and $S_{s}$ is allowable shear stress $=$ $55 \times 10^{6} \mathrm{MN} / \mathrm{m}^{2}$

The biogas planter designed and fabricate is shown in figure 2.0

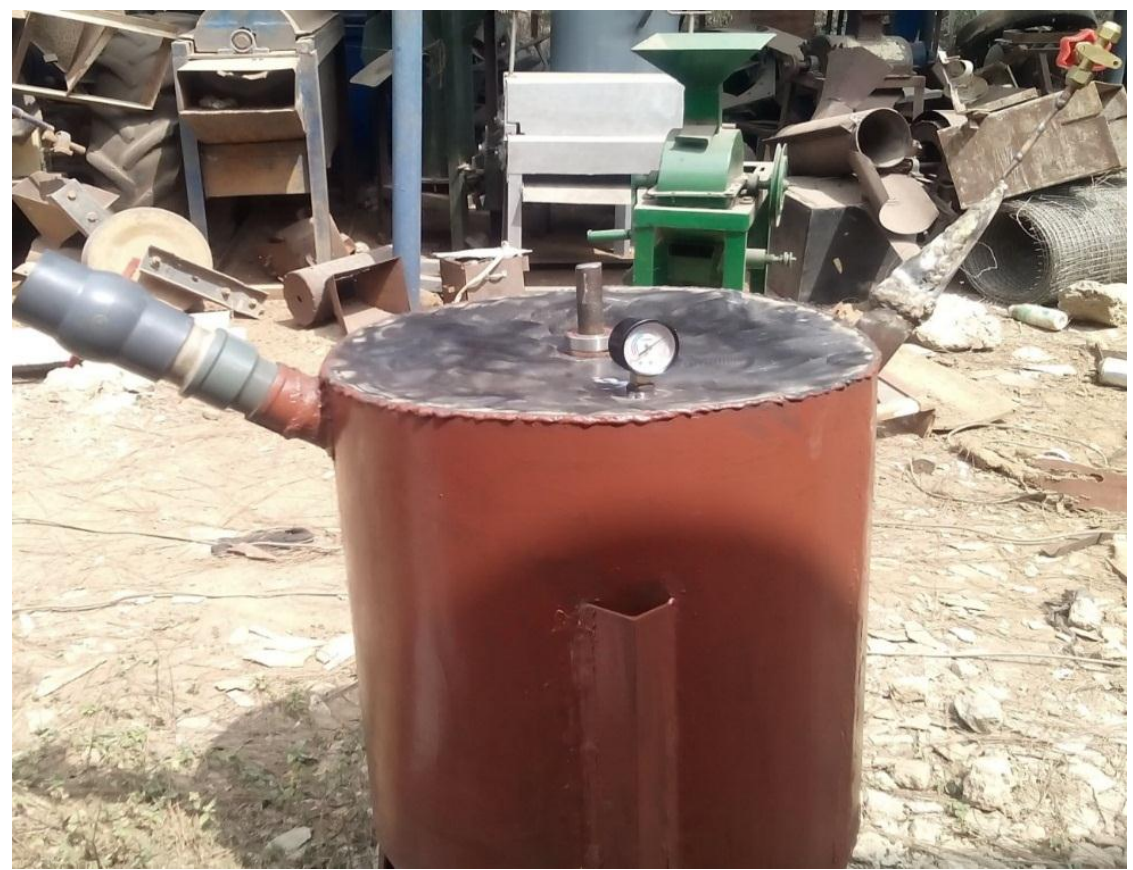

Fig 2.0:-Biogas plant

\section{Biogas Plant Operations}

The biogas digester unit is filled through the controlled inlet valve with the mixture of $5 \mathrm{~kg}$ each of CD, PD and SD with impure 25 liters of water as shown in figure 2.1. 


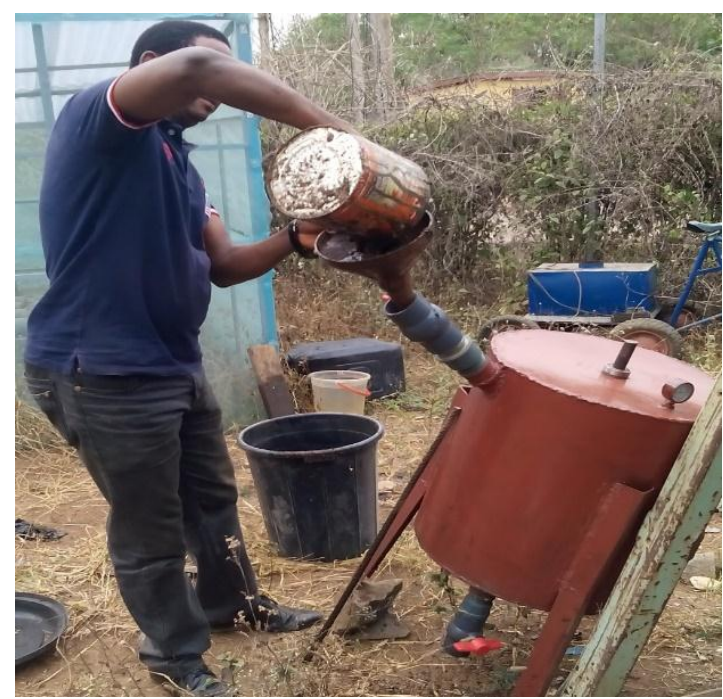

Fig 2.1:-Loading of the Biogas Plant

The stirrer which can be manually or electrically powered through $1.5 \mathrm{Hp}$ electric motor mixes the content together to a slurry form and allowed to ferment via anaerobic digestion for fourteen days. The stirring was repeated thereafter while the outlet valve is opened for the collection of gas produced. Temperature of the digester was maintained within the allowable temperature ranges for optimum gas production being; mesophilic, cycrophilic and thermophilic temperature ranges. A thermocouple was used to measure the temperature of the slurry.

\section{Results and Discussion:-}

\section{Results}

The results of the Physico-chemical property of the mixed substrates over a period of 25 days is as shown in Table 3.1 and Figure 3.0. While the effect of temperature on the $\mathrm{pH}$ of the substrates is presented in Table 3.2 and the chart of Figure 3.1.

Table 3.1:-Physicochemical Property of Substrates

\begin{tabular}{|c|c|c|}
\hline PARAMETERS & FRESH SUBTRATES & SUBTRATES AFTER DIGESTION \\
\hline Total Solids $(\%)$ & 83.5 & 22.6 \\
\hline Moisture content $(\%)$ & 13.5 & 74.4 \\
\hline Volatile solids $(\%)$ & 64.7 & 54.1 \\
\hline Ash content $(\%)$ & 34.6 & 45.6 \\
\hline $\mathrm{pH}$ & 6.6 & 7.2 \\
\hline Temperature $\left({ }^{\circ} \mathrm{C}\right)$ & 30.3 & 29.5 \\
\hline
\end{tabular}

Table 3.2:-Effect of temperature on $\mathrm{pH}$ level of the substrates

\begin{tabular}{|c|c|c|}
\hline Days & $\mathbf{p H}$ & Temp ( $\mathbf{}$ c) \\
\hline 1 & 6.7 & 31.8 \\
\hline 2 & 7 & 31.6 \\
\hline 3 & 7 & 31 \\
\hline 4 & 6.9 & 32.5 \\
\hline 5 & 6.8 & 32 \\
\hline 6 & 6.7 & 32.5 \\
\hline 7 & 6.9 & 33.3 \\
\hline 8 & 7.4 & 30.3 \\
\hline 10 & 7.2 & 28 \\
\hline 11 & 7 & 28.5 \\
\hline 12 & 7.1 & 29.5 \\
\hline 13 & 7.2 & 31 \\
\hline
\end{tabular}




\begin{tabular}{|c|c|c|}
\hline 14 & 7 & 33.5 \\
\hline 15 & 6.9 & 30 \\
\hline 16 & 6.8 & 29 \\
\hline 17 & 6.7 & 28.5 \\
\hline 18 & 6.7 & 30 \\
\hline 19 & 6.94 & 31 \\
\hline 20 & 6.8 & 29 \\
\hline 21 & 6.7 & 29 \\
\hline 22 & 6.8 & 30 \\
\hline 23 & 6.7 & 29 \\
\hline 24 & 6.8 & 30 \\
\hline 25 & 6.82 & 30 \\
\hline Mean & 6.9 & 29.26 \\
\hline
\end{tabular}

\section{Discussion:-}

\section{Analysis and Physicochemical Properties of the Substrates}

As presented in Figure 3.0, it was observed that there was a decrease in the total solids, volatile solids and temperature of the fresh substrates and after digestion.

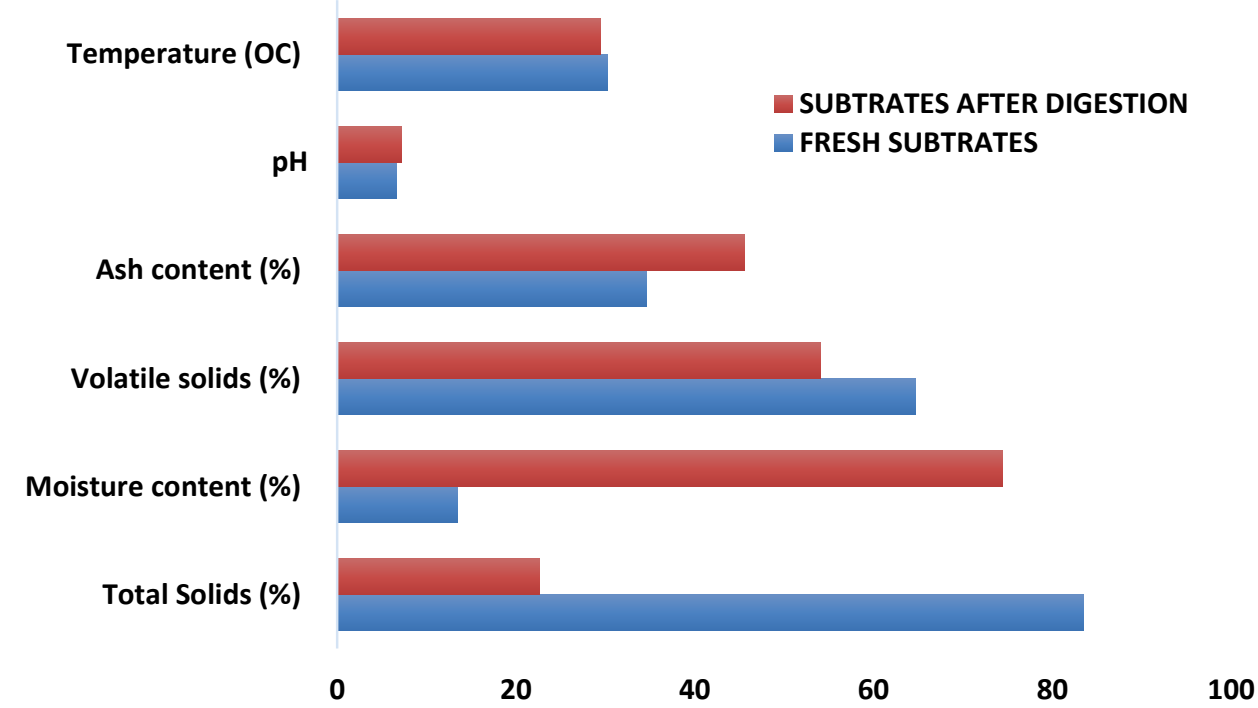

Fig. 3.0:-Physicochemical properties of biogas substrates

The total solid waste reduced from $83.5 \%$ to $22.6 \%$, also, the volatile content reduced from $64.7 \%$ and $54.1 \%$ and that of temperature from $30.3^{\circ} \mathrm{c}$ to $29.5^{\circ} \mathrm{c}$, this may be due to the utilization of the wastes by the microorganisms which agrees with the reports of Oyeleke et al., (2003), who stated that, the total solids and volatile solids reduce as methane yield increases. Whereas, the ash content increases from $34.6 \%$ to $45.6 \%$ and the $\mathrm{pH}$ level moves from 6.6 to 7.2 which is in agreement with the work of Hansen (2001) who reported that $\mathrm{pH}$ range of 6.8 through neutral to 7.4 is required for optimum biogas. It was also observed that as the temperature increases, the gas production increases as well, this was also the observation of Lawal et al., (2001) that biogas production is favored with an increased temperature and as temperature drops, so the rate of biogas production declines. The retention period for biogas production was twenty five days. This may be due to the accumulation of acids, exhaustion of nutrient or production of auto toxic substances by the microbes because this process is a batch culture system.

\section{Proximate Analysis and Physicochemical Properties}

The proximate analysis showed that at fresh state the volatile solid, total solid and moisture content for mixed substrates were; $64.7,83.5$ and 13.5 respectively and after the experiment the analysis also showed volatile solid, total solid and moisture content were; 54.1, 22.6 and 74.4 respectively. As the decomposition proceeded, the $\mathrm{pH}$ value gradually increased from 6.0 up to 7.4 indicating the stability of organic matter. Earlier studies have showed 
that $\mathrm{pH}$ range of 5.5 - 9.0 was suitable for microbial decomposition of organic materials, while the compositing process was most effective at $\mathrm{pH}$ values between 6.5 and 8.0 (Kalia and Singh, 1996; Philip and Itodo, 2001).

\section{Flammability of the gas}

An increase in the pressure of the biogas plant digester was observed on the seventh day of fermentation. This was attributed to biochemical reaction arising from the microbial activities of the substrates. Combustibility tests carried out shows blue flame with pop sound which was repeated and found positive after 24 days of digestion without any black fume.

\section{pH and Temperature}

As represented in the trend chart of Figure 3.1, it was discovered that the slurry changed from acidic to basic state. It was also observed that the acidity in the digester at the first week of the experiment produced low yield of biogas. During the early stage of decomposition, the acid forming bacteria were found to be breaking down the substrate with volatile fatty acids produced. This changed the values of the general acidity for the digesting material with the value of the $\mathrm{pH}$ falling below neutral. These changes assisted the microorganisms in the system to perform well which led to increase in the production of the biogas. The result was corroborated by related research carried out by Akintunde (2014).

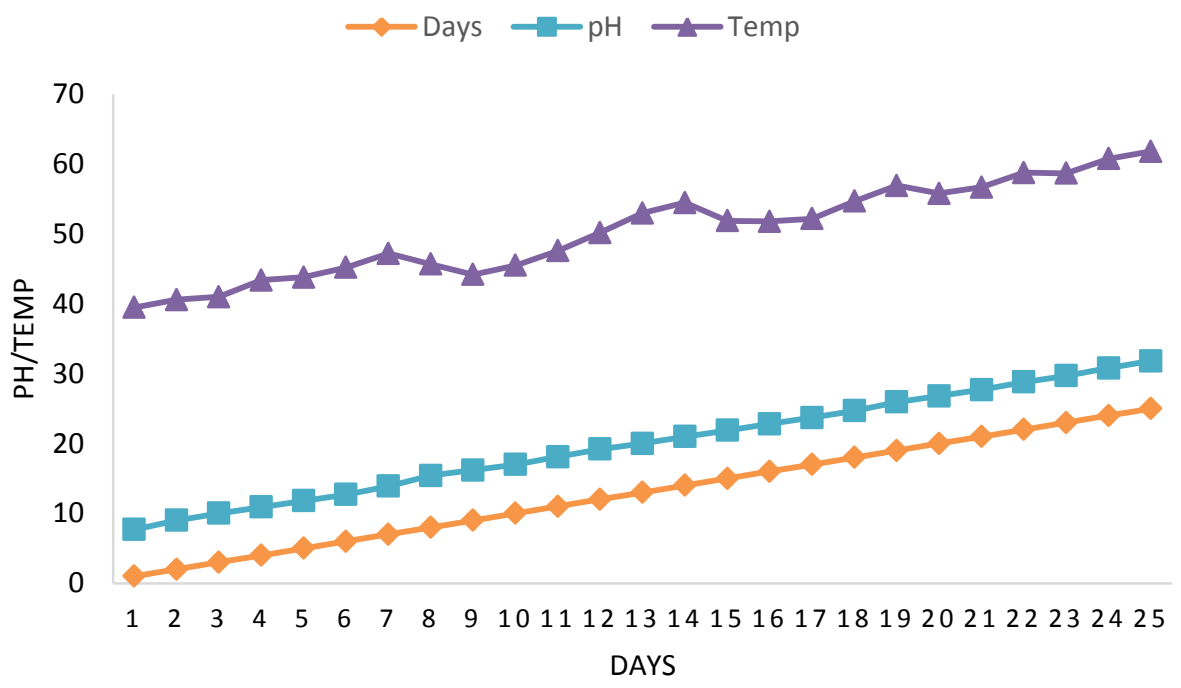

Fig 3.1:-Variation of combine $\mathrm{pH}$ and slurry temperature with retention time (Days)

\section{Conclusion:-}

A biogas digester that consist of inlet opener, outlet opener, a stirrer handle, spikes and cylindrical chamber has been designed, fabricated and evaluated. The result of this research showed that many of the micro-organisms associated with the fermentation of cow dung', swine dung' and poultry dropping originated from the substrate used. The biogas yield was dependent on the temperature of the environment where the digester was placed. The higher the temperature, the higher the methane gas produced. The $\mathrm{pH}$ on the other hand was affected by the activities of micro-organism, as the waste decomposes, the $\mathrm{pH}$ value gradually increased from 6.0 up to 7.4 indicating the stability of organic matter. A blue flame methane gas was produced when ignited after 25 days of the process which can be used for cooking. This research showed that waste products of livestock can be converted to gas for cooking and other domestic purpose.

\section{Reference:-}

1. Akinfiresoye, W.A., Olukunle, O.J., Oyerinde, A.S., Akintade, A.A. and Olutayo, A.S. $\quad$ (2018): Physico-Mechanical Characterisation of Wood Plastic Composites Produced from Indigenous Trees in Nigeria. International Journal of Research. Vol.6. Iss.2. ISSN. 2394-3629. 
2. Akintunde, M.A., Adegun, I.K. and Yaru, S.S. (2015): Comparative Study on Ignition Time of from Cattle Dung and Mixtures of Cattle Dung with Cassava Peels. Journal of Engineering Engineering Technology. Vol.1

3. Allen S. H., Alfred R.H. and Herman, G. L. (2009): Machine Design.Pdf. 2009th Ed.

4. Central Bank of Nigeria (CBN) (200): 'The Changing Structure of the Nigerian Economy and Implications for Development'. Research Department, Central Bank of Nigeria; Realm Communications Ltd, Lagos; 2000. August August

5. Fagbenle, R.O., Adenikinju, A., Ibitoye, F.I., Yusuf, A.O. and Alayande, O.(2006): Draft Final $\quad$ Report on Nigeria's Electricity Sector Executive Report. PHCN Gazette.

6. Famuyide, O.O., Adu. A.O. and Ojo, M.O. (2004): Socio-Economic Impacts of Deforestation in the Sudano- Sahelian Belt of Nigeria.Journal of Forestry Research and Management 1(1\&2):94-106.

7. Hansen, W. R. (2001): Methane Generating Farm Livestock Wastes. Publication of Farm Management Colorado State University, Colorado.

8. Imo, E.E. (2008): Challenges of Hydropower Development in Nigeria. Hydrovision Gazatte.

9. Kalia, A.K. andSingh, S.P. (2004): Development of a Biogas Plant. Energy Sources, 26: 707 -

714

10. Kayhanian, M.(2004): Ammonia Inhibition in High-Solids Bio-gasification: An overview and Practical Solutions. Journal of Environmental Technology. (1): 355-365.

11. Kehinde, O., Godswill, M., Anita, P. and Tobias R. (2014): Nigerian Wood Waste: A Dependable and Renewable Fuel Option for Power Production World Journal of Engineering and Technology, 2014, 2, 234248

12. Khurmi, R.S. and Gupta, J.K. (2005): A Textbook of Machine Design. Eurasia Publishing House (PVT) Ltd., Ram Nagar, New Delhi - 110055

13. Lawal, A. K., Ajuebor, F. N. \& Ojosu, J. O. (2001).Characteristic of piggery wastes feeds stock for determination of Design parameters to Biogas digester plant. Nigerian Journal of Research and Review in Science 2:193-198.

14. Nwaokocha, C.N. and Giwa, S.O. (2016): Investigation of Bio-Waste as Alternative Fuel for Cooking. 3 International Conference on Africa Development Issues. CU-ICAN.

15. Ofoefule, A. U., Uzodinma, E. O. and Onukwuli, O. D. (2009): Biogas Development in Africa. International Journal of Physical Sience. (4) 535-539.

16. Oyeleke, S. B., Onigbajo, H. O. and Ibrahim, K. (2003): Degradation of animal wastes (cattle dung) to produce methane (cooking gas). Proceeding of the eighth annual Conference of Animal Science Association of Nigeria (ASAN), pp. 168-169.

17. Philips, T. K. and Itodo, I. N. (2001): Determination of Suitable Material for Anaerobic Biogas-digesters," in Second International Conference and 23rd Annual General Meeting of the Nigerian, Lagos, 2001.

18. Oyedepo, S.O. (2012): Energy and sustainable development in Nigeria: the way forward. Elsevier Journal of Water Research (43):2717 - 2727

19. Zaher, U., Li, R., Jeppsson, U., Steyer, J.P. and Chen, S. (2009): General Integrated Solid Waste Co-digestion Model. Water Environment Research, Elsevier. 43: 2717 - 2727. 